\title{
Determination of soil water tension for irrigation management of sweet sorghum
}

\section{Determinação da tensão da água do solo para o manejo da irrigação do sorgo sacarino}

\author{
Karen Marcelle de Jesus Silva ${ }^{1 *}$; Ignacio Aspiazú ${ }^{2}$ Arley Figueiredo Portugal ${ }^{3}$; \\ Renato Mendes de Oliveira ${ }^{4}$; Polyanna Mara de Oliveira"; \\ Silvânio Rodrigues dos Santos²; José Aloísio Alves Moreira ${ }^{6}$
}

\begin{abstract}
Culturing of sweet sorghum is being considered as an excellent option for ethanol production, from an agronomical and industrial point of view. At present, information regarding the best soil water tension for beginning sweet sorghum irrigation is not available; hence, this study aimed to determine the adequate soil water tension under field conditions for beginning irrigation of four cultivars of sorghum. Two experiments were conducted at Nova Porteirinha, MG, in a randomized block design with subsubdivided plots having four replications. Each experiment comprised six treatments of soil water tension (plots)-20, 40, 60, 80, 100, and $120 \mathrm{kPa}$-for resuming sweet sorghum irrigation, and four sweet sorghum cultivars (subplots)-BRS 508, BRS 509, BRS 511, and CMSXS647. After planting, the soil water level in the plots was elevated to field capacity $(10 \mathrm{kPa})$, and then the treatments were applied. During treatment application, irrigation was resumed when the soil water tension reached the limit established in order to elevate the soil water tension to $10 \mathrm{kPa}$. The amount of water replaced during each irrigation was determined by generating a soil water retention curve for the experimental area. The following parameters were evaluated: green mass production, juice volume, soluble solids (Brix), and tons of Brix per hectare (TBH). The different soil water tensions and cultivars, agricultural year, and interaction between tension and year significantly affected $(\mathrm{p} \leq 0.05)$ the characteristics evaluated, according to the $F$ test. The agronomical characteristics of the evaluated cultivars showed linear relationship with water supply in the soil. According to TBH, irrigation of sweet sorghum needs to be performed when the soil tension reaches $20 \mathrm{kPa}$. The TBH values did not differ significantly among the four cultivars at the $5 \%$ significance level according to Tukey test.
\end{abstract}

Key words: Juice volume. Soluble solid. Sorghum bicolor. Tons of Brix per hectare. Water deficit.

1 Enga $^{\mathrm{a}}$ Agr $^{\mathrm{a}}$, Discente do Curso de Doutorado em Agronomia/Fitotecnia, Universidade Federal de Lavras, UFLA, Lavras, MG, Brasil. E-mail: karen marcelle@hotmail.com

2 Profs., Universidade Estadual de Montes Claros, UNIMONTES, Janaúba, MG, Brasil. E-mail: aspiazu@gmail.com; silvaniors@, yahoo.com.br

3 Pesquisador, Empresa Brasileira de Pesquisa Agropecuária, EMBRAPA Milho e Sorgo, Nova Porteirinha, MG, Brasil. E-mail: arley.portugal@embrapa.br

4 Eng ${ }^{\mathbf{o}}$ Agr ${ }^{\circ}$, Discente do Curso de Doutorado em Produção Vegetal, UNIMONTES, Janaúba, MG, Brasil. E-mail: renatoagronomo@ hotmail.com

5 Pesquisadora, Empresa de Pesquisa Agropecuária de Minas Gerais, EPAMIG, Nova Porteirinha, MG, Brasil. E-mail: polyanna. mara@epamig.br

6 In memorian.

* Author for correpondence 


\section{Resumo}

A cultura do sorgo sacarino vem sendo considerada uma ótima opção, sob os pontos de vista agronômico e industrial, para a produção de etanol. Como não há informações sobre a melhor tensão da água do solo para o início da irrigação do sorgo sacarino, objetivou-se determinar em campo a tensão de água do solo adequada para o início da irrigação de quatro cultivares. Foram conduzidos dois experimentos, em Nova Porteirinha, MG, no delineamento em blocos casualizados, no esquema de parcelas subsubdivididas, em quatro repetições. Cada um dos experimentos foi constituído por seis tratamentos de tensão da água do solo (parcelas); 20, 40,60, 80, 100 e $120 \mathrm{kPa}$, para o reinício da irrigação do sorgo sacarino, e de quatro cultivares de sorgo sacarino (subparcelas): BRS 508, BRS 509, BRS 511 e CMSXS647. Após o plantio, as parcelas tiveram a umidade do solo elevada à capacidade de campo $(10 \mathrm{kPa})$, quando a partir de então foram aplicados os tratamentos. Durante o período de aplicação dos tratamentos, sempre que a tensão de água no solo atingia o limite de tensão estabelecido, o sistema de irrigação do tratamento era acionado, funcionando o tempo necessário para elevar a tensão da água do solo a $10 \mathrm{kPa}$. A quantidade de água reposta em cada irrigação foi obtida com o auxílio da curva de retenção de água do solo da área experimental. Foram avaliados a produção de massa verde, volume de caldo, sólidos solúveis ( ${ }^{\circ}$ Brix) e toneladas de ${ }^{\circ}$ Brix por hectare (TBH). As diferentes tensões de água no solo, diferentes cultivares, ano agrícola e a interação entre as tensões e o ano afetaram significativamente $(\mathrm{p} £ 0,05)$ as características avaliadas, de acordo com o Teste F. As características agronômicas das cultivares avaliadas responderam linearmente ao aporte de água no solo. Considerando o parâmetro TBH, sugere-se que o início da irrigação do sorgo sacarino seja realizado quando o solo atingir a tensão de $20 \mathrm{kPa}$. Ainda considerando a TBH, as cultivares não diferiram entre si a 5\% de significância pelo teste de Tukey.

Palavras-chave: Sólidos solúveis. Volume de caldo. Déficit hídrico. Toneladas de ${ }^{\circ}$ Brix por hectare. Sorghum bicolor. Crop.

\section{Introduction}

Considering the possible depletion of oil sources and increasing concern regarding environmental issues, identifying alternative sources of fuels other than oil derivatives has become necessary. Among such fuels, ethanol is a promising alternative, since it is a renewable fuel and has physical and chemical characteristics similar to those of petrol. Among plants that have remarkable energy potential to be used as renewable energy sources, sugarcane, beetroot, and sweet sorghum are the most important ones.

The crop of sweet sorghum has become an excellent option considering its agronomic and industrial potential for the production of ethanol. Further, the production levels of sorghum are almost similar to those of sugarcane in the areas with low rainfall and likely in less-fertilized soils.

Drought tolerance is the main characteristic of sorghum that allows it to be cultivated in arid and semi-arid regions (MAGALHÃES et al.,
2012). Unlike other Gramineae crops, sorghum is of economic importance because of not only its tolerance to water deficit but also the possibility to cultivate it in unirrigated production systems and at times when rainfall distribution is irregular (XIN et al., 2009).

Among the various aspects of agricultural production, irrigation requires the highest amount of water and electricity and comprises the most efficient way to produce feed. In the future, the majority of agricultural production is speculated to be derived from irrigated production systems. Therefore, increasing the profitability of the irrigation process requires the production of more per unit of water applied, and this can be achieved by adequate irrigation management (MOREIRA et al., 2011).

Adequate and efficient use of water and electric energy becomes possible with correct irrigation management, that is, when the correct water depth is used for specific crops. The soil water content or tension measurements can be used to 
evaluate indirectly the water deficit of a crop. The measurement of soil water tension to control irrigation allows the extrapolation of results to other soils with little modifications. This is because water consumption by a plant occurs in response to water potential differences, which, in a certain way, has a similar effect on plant growth, regardless of the location.

Since information on the optimum water tension in the soil for beginning irrigation for sweet sorghum is not yet available, this study aimed to determine the adequate soil water tension for resuming irrigation of four cultivars of sorghum under field conditions.

\section{Materials and Methods}

The experiments were conducted at an experimental farm of the Brazilian Agricultural Research Corporation-Maze and Sorghum (Embrapa Milho and Sorgo) in the municipality of Nova Porteirinha, MG, located in the Brazilian semi-arid region $\left(43^{\circ} 16^{\prime} 18.2^{\prime \prime} \mathrm{W}\right.$ and $15^{\circ} 49^{\prime} 51^{\prime \prime} \mathrm{S}$; altitude, $540 \mathrm{~m}$; climate type, Aw, tropical with a dry winter, according to the classification of Köppen). The soil in this location is classified as red yellow latosol, with average texture, deep and very porous. Granulometric analysis revealed an average content of $120 \mathrm{~g} \mathrm{~kg}^{-1}$ of gross sand ( 2 to $0.2 \mathrm{~mm}$ ), $370 \mathrm{~g} \mathrm{~kg}^{-1}$ of fine sand ( 0.2 to $0.053 \mathrm{~mm}), 210 \mathrm{~g} \mathrm{~kg}^{-1}$ of silt, and $300 \mathrm{~g} \mathrm{~kg}^{-1}$ of clay in the $0-20-\mathrm{cm}$ layer. The meteorological conditions during the experimental period in 2013 and 2014 are shown in Figure 1.

Figure 1. Temperature and precipitation data during the experiment conducted at Nova Porteirinha, MG, obtained from the INMET-Instituto Nacional de Meteorologia in 2013 and 2014.

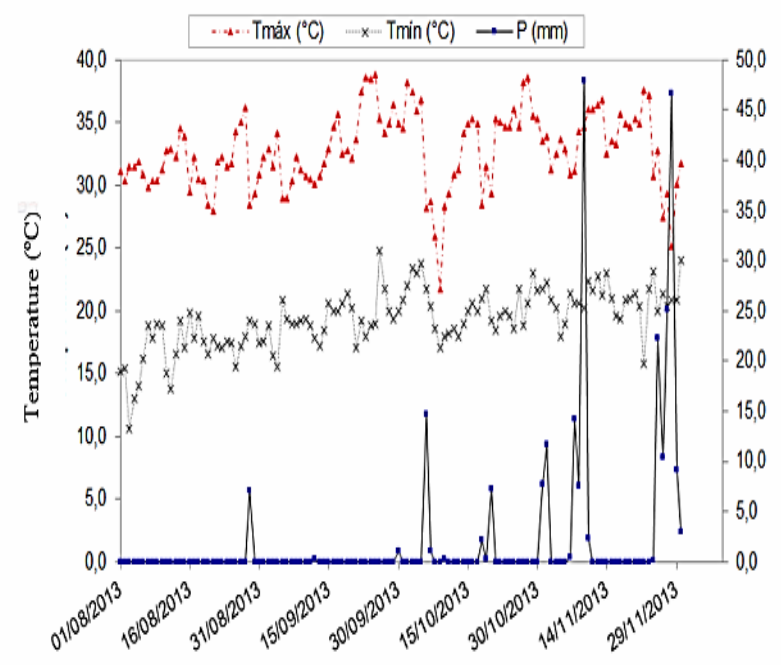

Two experiments were conducted during the winter period: for the first experiment, planting was performed on August 8, 2013; for the second experiment, planting was performed on July 30, 2014.

In both the experiments, treatments comprised six values of soil water tension, i.e., 20, 40, 60,

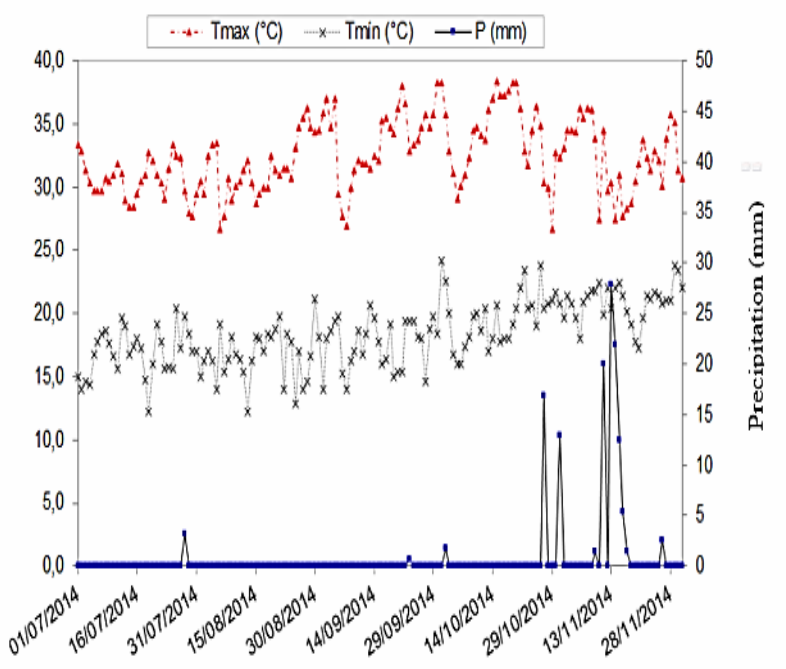

80,100 , and $120 \mathrm{kPa}$, for resuming irrigation of sweet sorghum, and four cultivars, i.e., BRS 508, BRS 509, BRS 511, and CMSXS647. Experiments were performed in a randomized block design, with sub-subdivided plots having four replications. The different levels of tension were the plots, sorghum cultivars, subplots, and years of evaluation of the sub-subplots. 
Soil was prepared in a conventional manner: it was ploughed once and harrowed twice before planting. The sorghum cultivars were sown manually, with subsequent thinning in order to adjust the plant stands to approximately 120,000 plants ha-1. The rows were spaced at $0.7 \mathrm{~m}$, and each plot comprised four 5-m length rows; the two central rows of the plot were considered as the useful area.

The recommendations for liming and fertilization were based on the fifth approximation (CFSEMG, 1999), with $300 \mathrm{~kg} \mathrm{ha}^{-1}$ of NPK $(8: 28: 16)+\mathrm{Zn}$ applied deep in the soil in continuous ridges before planting and subsequent application of $200 \mathrm{~kg} \mathrm{ha}^{-1}$ urea in the cover.

Weed control was performed using the preemergent herbicide Atrazine. The plots were sprayed to control pests and diseases, as required. Sorghum was harvested 120 days after sowing in both the experiments.

After planting, all plots had their soil moisture elevated to field capacity $(10 \mathrm{kPa})$, and then the treatments were applied after crop establishment (plants with four leaves open).

Localized irrigation was performed using a drip system, with a lateral line for each plant row and emitters spaced at $0.45 \mathrm{~m}$ between the rows, with a flow rate of $2.5 \mathrm{~L} \mathrm{~h}^{-1}$. During the treatment period, the plots were irrigated when the soil water tension reached the established limit, and the time required to elevate the soil water tension to $10 \mathrm{kPa}$ (field capacity) was recorded. Daily readings of tension were obtained using electric resistance sensors of granular matrix (Watermark ${ }^{\circledR}$ ) installed at a depth of $0.20 \mathrm{~m}$ on the sides of the central rows of each plot, and the values were converted to humidity by plotting a soil-water retention curve.

The curve was plotted by collecting 4 samples from different sites of the experimental area by using volumetric rings ( $0-0.20 \mathrm{~m}$ layer), and humidity for each tension level was determined using a Richard's chamber at saturation; the averages were used at each point for the adjustment of the curve. The results were adjusted using equation (1) proposed by Van Genuchten (1980).

$$
\theta=0,1411+\frac{(0,3149-0,1411)}{\left[1+(0,432 \times \psi)^{1,3379}\right]^{0,2526}}
$$

where $\theta=$ humidity $\left(\mathrm{cm}^{3} \cdot \mathrm{cm}^{-3}\right)$ and $\psi=$ matric tension $(\mathrm{kPa})$.

The green mass production, juice volume, total soluble solids (Brix), and tons of Brix per hectare (TBH) were evaluated.

All plants from the useful area of the plot were weighed to obtain the green mass of all plant parts (culm, leaf, and panicle). Next, a sample of ten plants was randomly collected for analyzing juice mass and total soluble solids. The juice was extracted using a low-efficiency electric mill. Subsequently, the juice was weighed, and the volume was measured using a beaker graduated in milliliters; the soluble solid content (Brix) was then analyzed using a digital refractometer. The percentage of extraction was calculated from the relation between juice weight and culm weight. TBH is the product of green mass yield for Brix and for the efficiency of juice extraction.

Sorghum was harvested at 120 days after sowing in both the experiments, when the grains of the panicles reached physiological maturity, according to the recommendations of Teixeira et al. (1999).

The data were submitted to analysis of variance; when the tension effects were significant, they were adjusted using regression models. The remaining significant effects were analyzed using average comparison by using the Tukey test at the 5\% significance level. For the quantitative factors, models were chosen based on the biological phenomenon according to the significance of the regression coefficient by using the $F$ test at the $5 \%$ significance level, and the correlation coefficient $\left(\mathrm{R}^{2}\right)$ was determined. All analyses, including regression analysis for different tensions, were conducted using the statistical program SISVAR ${ }^{\circledR}$ (FERREIRA, 2011). 


\section{Results and Discussion}

During the two production cycles, irrigation frequencies were higher in the treatments with lower soil water tension (Table 1), as expected. The total precipitation (Figure 1) in the $2013(242 \mathrm{~mm})$ and
$2014(128.5 \mathrm{~mm})$ cycles and the irrigation depths applied in each treatment revealed that more water was made available to the plants in the 2013 cycle, corresponding to $33.0 \%$ and $23.6 \%$ water in the 20 and $120 \mathrm{kPa}$ treatments, respectively, compared to that in the 2014 cycle (Table 1).

Table 1. Number of irrigations (NI); water depths applied (LL); and total water, including precipitation (LL $+\mathrm{P})$ in the treatments during each production cycle.

\begin{tabular}{ccccccc}
\hline \multirow{2}{*}{$\begin{array}{c}\text { TENSION } \\
(\mathbf{k P a})\end{array}$} & \multicolumn{2}{c}{$\mathbf{2 0 1 3}$} & \multicolumn{2}{c}{$\mathbf{2 0 1 4}$} \\
\cline { 2 - 7 } & $\mathbf{N I}$ & $\mathbf{L L}(\mathbf{m m})$ & $\mathbf{L L}+\mathbf{P}(\mathbf{m m})$ & $\mathbf{N I}$ & $\mathbf{L L} \mathbf{( m m})$ & $\mathbf{L L}+\mathbf{P}(\mathbf{m m})$ \\
\hline $\mathbf{2 0}$ & 22 & 173.8 & 415.8 & 19 & 150.1 & 278.6 \\
$\mathbf{4 0}$ & 13 & 189.8 & 431.8 & 14 & 204.4 & 332.9 \\
$\mathbf{6 0}$ & 9 & 161.1 & 403.1 & 8 & 143.2 & 271.7 \\
$\mathbf{8 0}$ & 5 & 100.5 & 342.5 & 6 & 120.6 & 249.1 \\
$\mathbf{1 0 0}$ & 4 & 86.4 & 328.4 & 4 & 86.4 & 214.9 \\
$\mathbf{1 2 0}$ & 2 & 45.4 & 287.4 & 4 & 90.8 & 219.3 \\
\hline
\end{tabular}

Figure 2. Green mass productivity $\left(\mathrm{t} \mathrm{ha}^{-1}\right)$ of four cultivars of sweet sorghum with regard to soil water tension in Nova Porteirinha, MG, in 2013 and 2014.
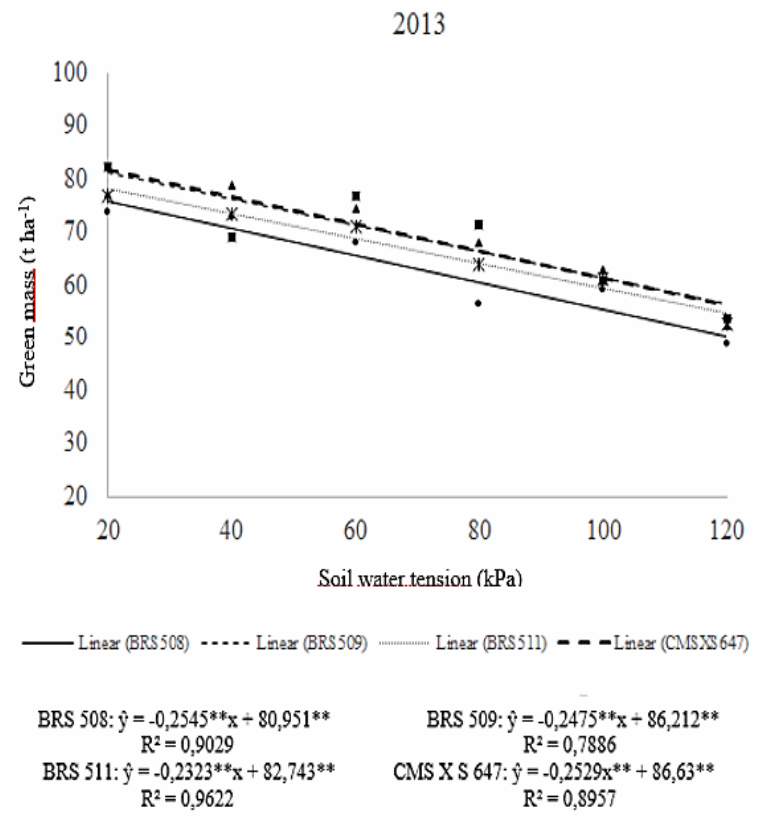

The different soil water tensions, different cultivars, agricultural year, and interaction between tensions and year significantly ( $\mathrm{p} 0.05$ ) affected the characteristics evaluated, according to the $F$ test.

For the variable green mass productivity, the tension of $20 \mathrm{kPa}$ increased the green mass

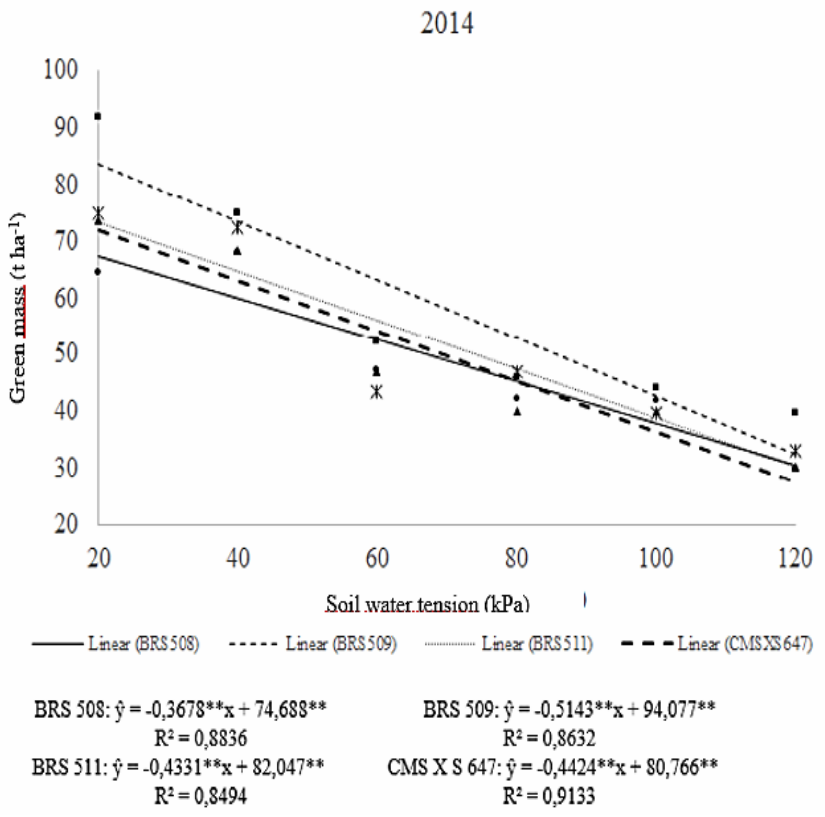

productivity of the cultivars, and this variable showed a decreasing linear trend with increasing soil water tension (Figure 2). No significant difference was observed for this variable between the two tensions $(20 \mathrm{kPa}$ and $40 \mathrm{kPa}$ ) between the years 2013 and 2014 (Table 2). 
The BRS 509 cultivar showed the highest production of green mass during the two cultivation years, with an average of $63.48 \mathrm{tha}^{-1}$ (Table 3 ). The overall green mass was higher than that reported by Souza et al. (2011) who evaluated the performance of 25 cultivars of sweet sorghum in two planting seasons; their work was also carried out in the north of Minas, Gerais, under an unirrigated production system, but the plots received complementary irrigation during summer periods. In their study, the overall average production of green mass was equal to $51.13 \mathrm{t} \mathrm{ha}^{-1}$ in the joint analysis. In this study, the overall average production of green mass was $66.86 \mathrm{t} \mathrm{ha}^{-1}$ and $52.14 \mathrm{t} \mathrm{ha}^{-1}$ in 2013 and 2014 , respectively. However, the cultivar CMSXS647, which was used in both the studies, showed better average production of green mass $\left(46.00 \mathrm{t} \mathrm{ha}^{-1}\right.$ in autumn and $67.81 \mathrm{t} \mathrm{ha}^{-1}$ in winter) in the study by Souza et al. (2011) compared to that obtained in the present study (59.37 $\mathrm{t} \mathrm{ha}^{-1}$ on an average during the two years of cultivation). These results suggest the relevance of adequate irrigation management to obtain greater productivities, since the total amount of water applied during the treatments of 20 and $40 \mathrm{kPa}$ in both the cultivation years was smaller than the water consumed during the normal growth of sorghum, which is $450 \mathrm{~mm}$ on an average (EMBRAPA-MILHO E SORGO, 2015).

Table 2. Averages of the characteristics of green mass $\left(\mathrm{t} \mathrm{ha}^{-1}\right)$, juice volume $\left(\mathrm{m}^{3} \mathrm{ha}^{-1}\right)$, and total soluble solids $(\mathrm{Brix})$ of the four sweet sorghum cultivars subjected to six soil water tensions (kPa) at Nova Porteirinha, MG, in 2013 and 2014.

\begin{tabular}{cccccccc}
\hline \multirow{2}{*}{ TENSION } & \multicolumn{2}{c}{ GREEN MASS } & & \multicolumn{2}{c}{ JUICE VOLUME } & \multicolumn{2}{c}{ BRIX } \\
\cline { 2 - 3 } \cline { 6 - 8 } & ANO 2013 & ANO 2014 & & ANO 2013 & ANO 2014 & ANO 2013 & ANO 2014 \\
\hline 20 & $77.42 \mathrm{a}$ & $76.27 \mathrm{a}$ & & $2.31 \mathrm{~b}$ & $2.79 \mathrm{a}$ & $22.15 \mathrm{a}$ & $21.33 \mathrm{a}$ \\
40 & $73.49 \mathrm{a}$ & $70.86 \mathrm{a}$ & & $2.34 \mathrm{~b}$ & $2.71 \mathrm{a}$ & $22.78 \mathrm{a}$ & $22.09 \mathrm{a}$ \\
60 & $72.46 \mathrm{a}$ & $47.41 \mathrm{~b}$ & & $1.88 \mathrm{a}$ & $1.54 \mathrm{~b}$ & $22.58 \mathrm{a}$ & $21.17 \mathrm{~b}$ \\
80 & $64.90 \mathrm{a}$ & $43.78 \mathrm{~b}$ & & $1.76 \mathrm{a}$ & $1.32 \mathrm{~b}$ & $23.16 \mathrm{a}$ & $21.05 \mathrm{~b}$ \\
100 & $61.02 \mathrm{a}$ & $41.27 \mathrm{~b}$ & & $1.92 \mathrm{a}$ & $1.15 \mathrm{a}$ & $22.94 \mathrm{a}$ & $19.47 \mathrm{~b}$ \\
120 & $51.87 \mathrm{a}$ & $33.23 \mathrm{~b}$ & & $1.40 \mathrm{a}$ & $0.86 \mathrm{~b}$ & $23.41 \mathrm{a}$ & $19.66 \mathrm{~b}$ \\
\hline
\end{tabular}

Averages followed by the same letter in the rows do not differ significantly according to the Tukey test at the $5 \%$ significance level $(\mathrm{p} £ 0.05)$.

Table 3. Averages of two cultivation years (2013 and 2014) of the characteristics of green mass ( $\left.\mathrm{t}^{-1}\right)$, juice volume $\left(\mathrm{m}^{3} \mathrm{ha}^{-1}\right)$, and soluble solids (Brix) evaluated in the four sweet sorghum cultivars at Nova Porteirinha, MG.

\begin{tabular}{cccc}
\hline CULTIVAR & GREEN MASS & JUICE VOLUME & BRIX \\
\hline BRS 508 & $56.04 \mathrm{~b}$ & $1.56 \mathrm{~b}$ & $22.47 \mathrm{a}$ \\
BRS 509 & $63.48 \mathrm{a}$ & $1.83 \mathrm{a}$ & $22.01 \mathrm{ab}$ \\
BRS 511 & $59.10 \mathrm{~b}$ & $1.89 \mathrm{a}$ & $21.62 \mathrm{bc}$ \\
CMSXS647 & $59.37 \mathrm{~b}$ & $2.05 \mathrm{a}$ & $21.16 \mathrm{c}$ \\
\hline
\end{tabular}

Averages followed by the same letter in the columns do not differ significantly according to the Tukey test at the $5 \%$ significance level ( $\mathrm{p} £ 0.05)$.

According to Forsthofer et al. (2006), the production of phytomass depends on factors such as the duration of crop development and plant reserve availability.

Many studies have shown that the productivity of crops decreases with an increase in soil water tension, since water limitation in the soil affects the development of all vegetative structures of plants and reduces their capacity of phytomass production (BILIBIO et al., 2010; CARLESSO; SANTOS, 1998; FABEIRO et al., 2002; SCHLICHTING, 2012). 
Bergamaschi et al. (2006) evaluated the effect of water deficit in maize during 10 years and found that, on average, the maximum irrigation increased the yield of grains by approximately $70 \%$ in three hybrids of maize (Pioneer 3230, Pioneer 3063, and Pioneer 32R21) compared to that in the nonirrigated crop.

In this study, a reduction of $33 \%$ and $56.43 \%$ was noted in the green mass production of plants cultivated under a soil water tension of $20 \mathrm{kPa}$ compared to those cultivated at $120 \mathrm{kPa}$ in 2013 and 2014, respectively, although sorghum is considered to be tolerant to water stress. Therefore, with regard to productivity, soil water tension of $40 \mathrm{kPa}$ was optimum to determine the time for resumption of irrigation since the effect of this treatment was not different from that after treatment at $20 \mathrm{kPa}$. However, maintaining soil water at this level of tension $(40 \mathrm{kPa})$ requires frequent irrigation, which might increase the production costs due to higher water and electric energy consumption. The present study was performed in a semi-arid region where water is a rare resource. For the sweet sorghum crop, adequate soil water tension cannot be determined based on only one characteristic; this will be discussed below.

The juice volume was high for all cultivars at the tension of $20 \mathrm{kPa}$ for both the cultivation years (Figure 3). However, the average juice volume was greater in 2014 than in 2013 at the same tension (2.31 $\mathrm{m}^{3} \mathrm{ha}^{-1}$ and $2.79 \mathrm{~m}^{3} \mathrm{ha}^{-1}$ for 2013 and 2014, respectively; Table 2). This could be explained by the occurrence of greater rain during a specific period of the year, which increased the juice volume for treatments above $70 \mathrm{kPa}$.

Figure 3. Juice volume $\left(\mathrm{m}^{3} \mathrm{ha}^{-1}\right)$ of the four sweet sorghum cultivars with regard to the soil water tension at Nova Porteirinha, MG, in 2013 and 2014.

ANO: 2013

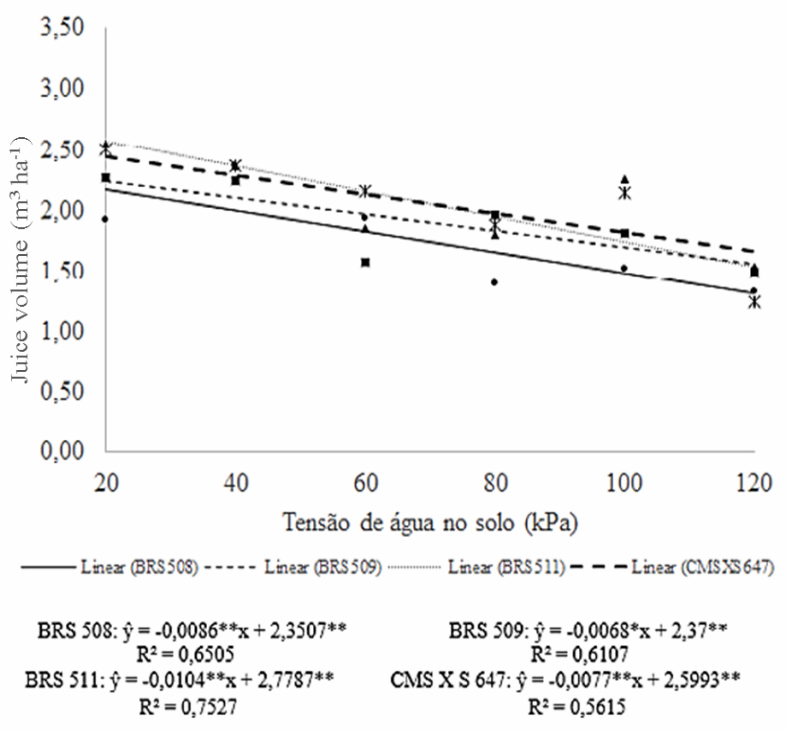

ANO: 2014

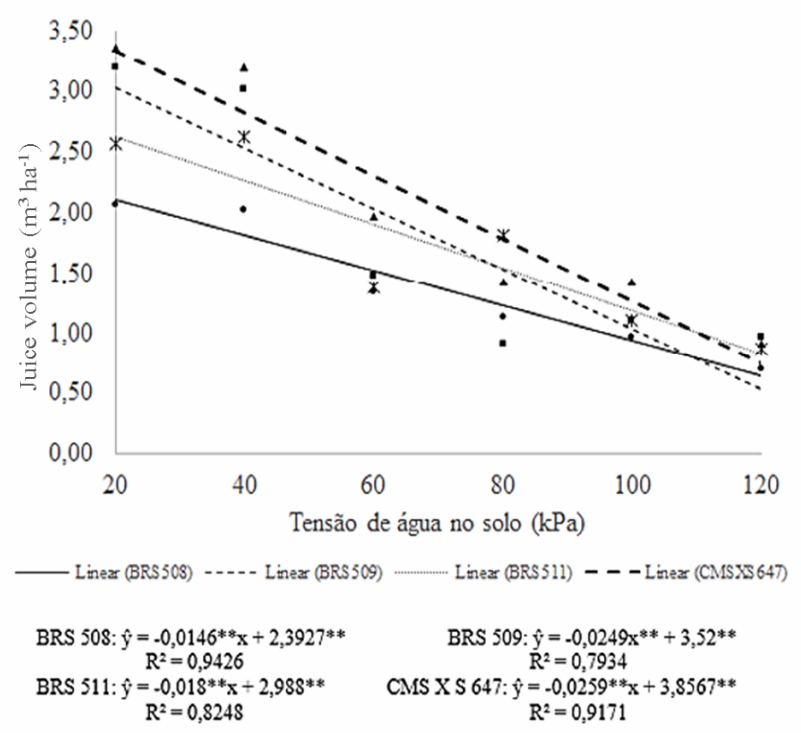


BRS 508 showed lower juice volumes than those observed in the remaining cultivars (Table 3); this could be attributed to the genetic characteristics of the cultivar. The juice volume of the cultivars decreased linearly with increasing soil water tension (Figure 3). This finding is explained by the fact that juice production is related to water availability, and an increase in soil water tension results from the decrease in the water available for plants.

Cultivar BRS 509 showed higher accumulation of green mass as well as higher juice volume. However, Pereira Filho et al. (2013) suggested that higher juice volume does not always result in greater sugar production, and thus higher ethanol yield in sorghum.
In 2013, the values of total soluble solids (Brix) were higher than the other variables evaluated when a tension of $120 \mathrm{kPa}$ was applied. However, in 2014, higher total soluble solids was obtained with the application of $20 \mathrm{kPa}$ tension (Figure 4) for all the evaluated cultivars. This could be explained by the fact that sugar content in the juice, and thus its conversion to ethanol, should not depend exclusively on the water available, but also on the cultivar, environmental factors, harvest season, and efficiency during transport and industrial conversion processes (PEREIRA FILHO et al., 2013). Further, the volume of rainfall was higher in 2013, which could have contributed to the increase in the values of total soluble solids (Brix).

Figure 4. Total soluble solid content (Brix) of the four sweet sorghum cultivars with regard to soil water tension at Nova Porteirinha, MG, in 2013 and 2014

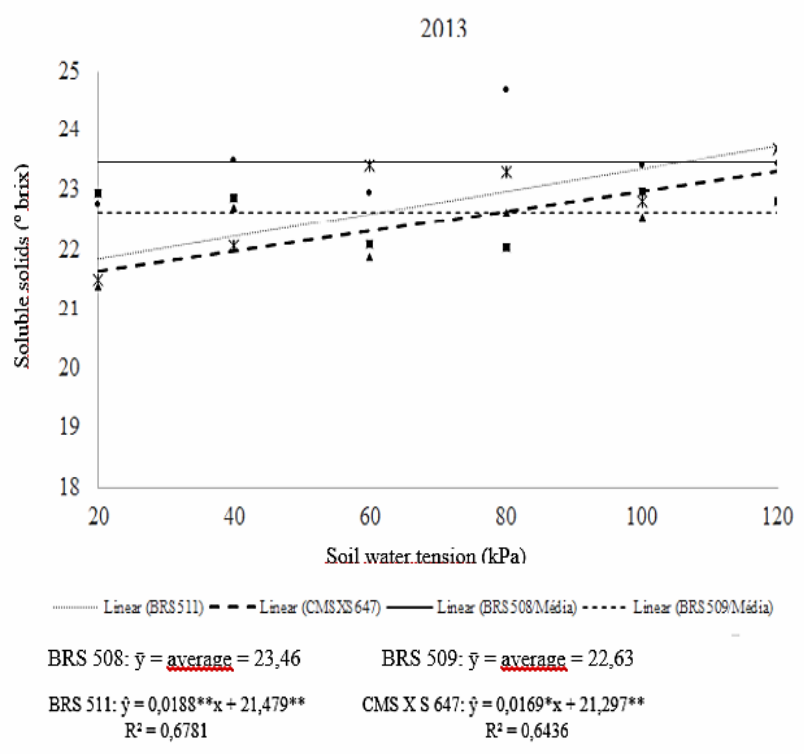

In this study, the Brix values varied between 19.47 and 23.41, and they were above those proposed by (MAY et al., 2012), since the average Brix required for commercial cultivars varies from 15 to 19 Brix.

No significant difference was found among the cultivars with regard to Brix at the $5 \%$ significance level by the Tukey test (Table 3). Souza et al. (2014)

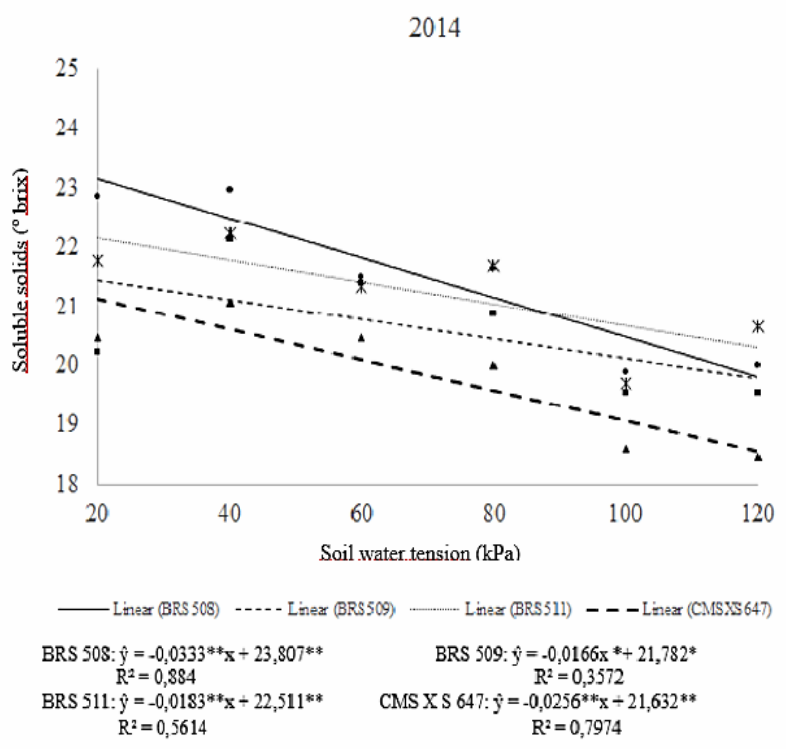

showed that cultivar BRS 508 had greater total solid content (17.8 Brix) than those of the remaining cultivars. In this study, the cultivar BRS 508 showed the lowest juice volume; however, the variable soluble solid content (Brix) was not different from that of the other cultivars investigated, suggesting that a decrease in water volume of plants increases their soluble solid content. 
Oliveira et al. (2014) evaluated the agronomical performance of 25 genotypes of sweet sorghum from the Breeding Program of the Agricultural Research Corporation-Maize and Sorghum (Embrapa Milho e Sorgo; BR501, BR505, BRS506, BRS509, CMSXS630, CMSXS634, CMSXS642, CMSXS643, CMSXS644, CMSXS646, CMSXS647, CMSXS648, 201027013, 201027014, 201027015, 201027016, 201027017, 201027018, 201027019, 201027020, BRS601, Sugargraze, V82391, V82392, and V82393) in the region of Cáceres-MT and found that the Brix average between the genotypes was $16.51 \%$. Similar results were obtained by Tardin et al. (2012) who evaluated 25 genotypes of sweet sorghum in Sinop-MT and showed that the genotypes had an average Brix value of $13.6 \%$, varying from $19.4 \%$ to $6.6 \%$. In this study, the Brix value was higher than that reported by these authors, with $22.84 \%$ and $20.79 \%$ Brix for 2013 and 2014, respectively.

The Brix values obtained in this study were higher than those in other studies performed in the same region. Albuquerque et al. (2012) cultivated sorghum in the north of Minas and found Brix values between $16.47 \%$ and $19.50 \%$ for the localities Nova Porteirinha and Jaíba during summer cultivations whereas, in this study, the cultivation was performed in winter. Brix of sweet sorghum juice is known to be influenced by the length of day and global radiation, which might have caused the differences among the studies (TEIXEIRA et al., 1999).

Souza et al. (2011) showed that the variation in the characteristic soluble solids, which had higher overall average in autumn, could be associated with the influence of climatic conditions during the cultivation cycle, that is, a minor volume of rainfall, greater physiological requirements for water by plants, and thus greater soluble solid content in the juice.

Prasad et al. (2007) reported that the ideal period for harvesting sorghum is when the juice has $15.5 \%$ to $16.5 \%$ Brix; this juice has high fermentation quality, and thus, can be used to maximize the production of ethanol per hectare. These results are consistent with those of the present study.

Teixeira et al. (1999) cultivated sweet sorghum to determine the influence of cutting season on the sugar content in the culm and reported that late planting in the agricultural year 1986/87 affected the yield of green mass, as well as decreased the sugar content in the culm.

The productivity in tons of Brix per hectare (TBH) is shown in Figure 5. Higher yield was obtained when less energy was required for soil water retention $(20 \mathrm{kPa})$. Since this parameter is a product of green mass yield, Brix, and the efficiency of juice extraction, the decision for determining the adequate tension for beginning sorghum irrigation needs to be made considering this parameter, the TBH.

The value for Brix in 2013 suggests that tension greater than $100 \mathrm{kPa}$, which corresponds to an applied water depth of $86.4 \mathrm{~mm}$, would be ideal; however, with this tension, the green mass production would decrease, leading to a decrease in TBH. Therefore, obtaining a balance between Brix and green mass production is necessary, while considering the irrigation costs by conducting economic analysis to determine the adequate tension for the irrigation management of sorghum. However, when only the relation between soil water tension and TBH is considered, the irrigation for sweet sorghum should be initiated when the soil reaches a tension of $20 \mathrm{kPa}$, which corresponded to applied water depths of $173.8 \mathrm{~mm}$ and $150.1 \mathrm{~mm}$ in 2013 and 2014, respectively, since the cultivars showed a positive growth trend with improved water supply in the soil. Nonetheless, the TBH did not differ significantly among the cultivars at the $5 \%$ significance level by Tukey test (Table 4 ). 
Figure 5. Production in tons Brix per hectare (TBH) of the four sweet sorghum cultivars with regard to soil water tension at Nova Porteirinha, MG, in 2013 and 2014.

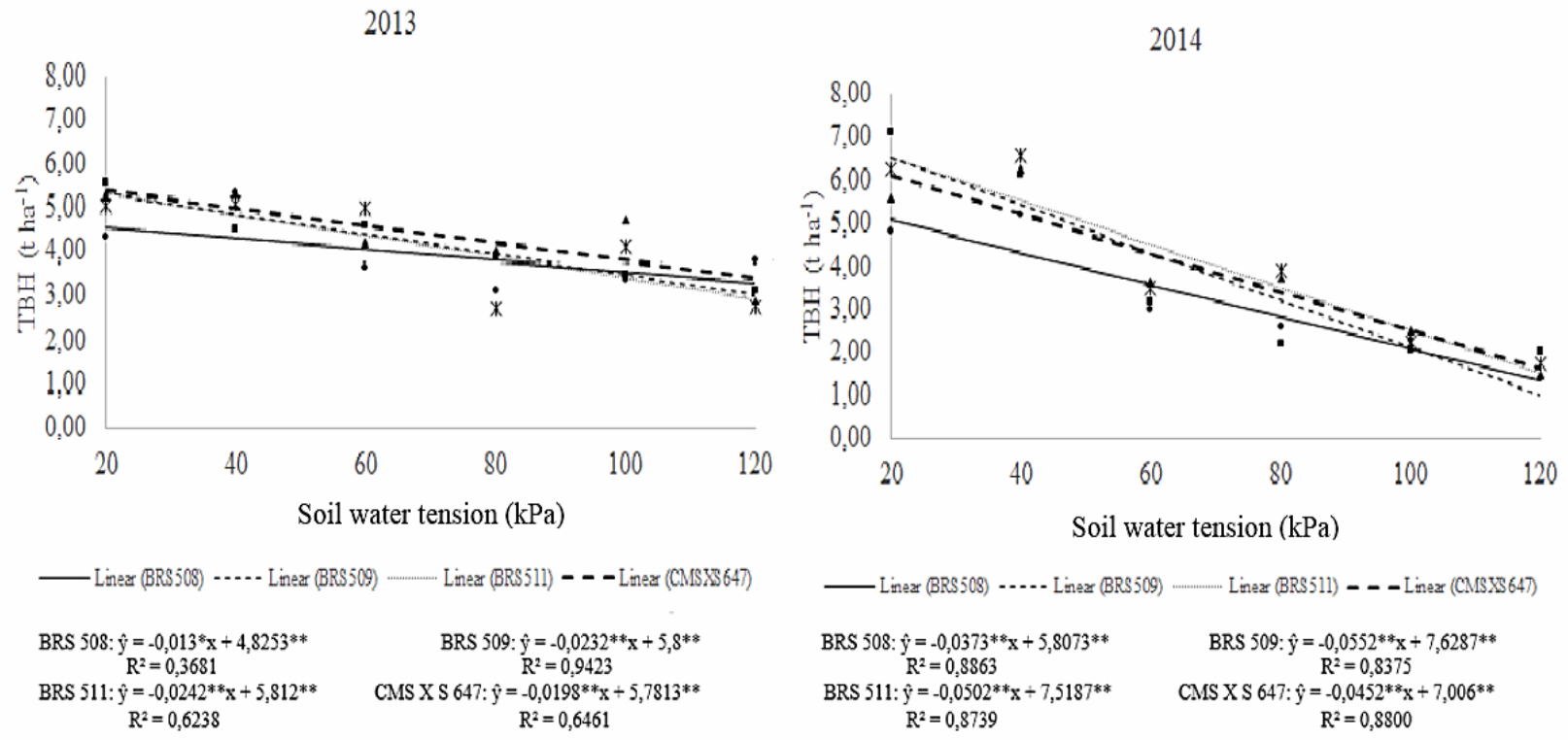

Table 4. Average of production of tons Brix per hectare (TBH) of four sweet sorghum cultivars at Nova Porteirinha, MG, in 2013 and 2014.

\begin{tabular}{cc}
\hline CULTIVAR & TBH $\left(\mathbf{t ~ h a}^{\mathbf{1}}\right)$ \\
\hline BRS 508 & $3.56 \mathrm{~b}$ \\
BRS 509 & $3.97 \mathrm{ab}$ \\
BRS 511 & $4.06 \mathrm{a}$ \\
CMSXS647 & $4.12 \mathrm{a}$ \\
\hline
\end{tabular}

Averages followed by the same letter in the column do not differ significantly according to the Tukey test at the $5 \%$ significance level $(\mathrm{p} \leq 0.05)$.

\section{Conclusions}

The agronomical characteristics of the evaluated cultivars responded linearly with water level in the soil.

Considering $\mathrm{TBH}$, irrigation of sweet sorghum needs to be resumed when the soil water tension reaches $20 \mathrm{kPa}$.

Further, the TBH was not significantly different among the cultivars at the $5 \%$ significance level by the Tukey test.

\section{Acknowledgments}

The authors would like to thank FAPEMIG, CNPq, CAPES, Embrapa-Milho e Sorgo and Petrobrás-for their support.

\section{References}

ALBUQUERQUE, C. J. B.; TARDIN, F. D.; PARRELA, R. A. C.; GUIMARÃES, A. S.; OLIVEIRA, R. M.; SILVA, K. M. J. Sorgo sacarino em diferentes arranjos de plantas e localidades de Minas Gerais, Brasil. Revista Brasileira de Milho e Sorgo, Sete Lagoas, v. 11, n. 1, p. 69-85, 2012. 
BERGAMASCHI, H.; DALMAGO, G. A.; COMIRAN, F.; BERGONCI, J. I.; MÜLLER, A. G.; FRANÇA, S.; SANTOS, A. O.; RADIN, B.; BIANCHI, C. A. M.; PEREIRA, P. G. Déficit hídrico e produtividade na cultura do milho. Pesquisa Agropecuária Brasileira, Brasília, v. 41, n. 2, p. 243-249, 2006.

BILIBIO, C.; CARVAlHO, J. A.; MARTINS, M.; REZENDE, F. C.; FREITAS, E. A.; GOMES, L. A. A. Desenvolvimento vegetativo e produtivo da berinjela submetida a diferentes tensões de água no solo. Revista Brasileira de Engenharia Agrícola e Ambiental, Campina Grande, v. 14, n. 7, p. 730-735, 2010.

CARLESSO, R.; SANTOS, R. F. Déficit hídrico e os processos morfológico e fisiológico das plantas. Revista Brasileira de Engenharia Agrícola e Ambiental, Campina Grande, v. 2, n. 3, p. 287-294, 1998.

COMISSÃO DE FERTILIDADE DO SOLO DO ESTADO DE MINAS GERAIS - CFSEMG. Recomendação para uso de corretivos e fertilizantes em Minas Gerais: $5^{\text {a }}$ aproximação. Sugestões de adubação para grandes culturas anuais ou perenes-Sorgo. Viçosa, MG: UFV, 1999. 325 p.

EMPRESA BRASILEIRA DE PESQUISA AGROPECUÁRIA - EMBRAPA. EMBRAPA Milho e Sorgo. Irrigação: culturas do milho, sorgo e milheto irrigados. Sete Lagoas: EMBAPA Milho e Sorgo, 2015. Disponível em: <http://www.cnpms.embrapa.br/irriga/ ajudairriga.html $>$. Acesso em: 15 ago. 2015.

FABEIRO, C.; SANTA OLALLA, F. M.; JUAN, J. A. Production of muskmelon (Cucumis melo L.) under controlled deficit irrigation in a semi-arid climate. Agricultural Water Management, Chicago, v. 54, n. 2, p. 93-105, 2002.

FERREIRA, D. F. SISVAR: a computer statistical analysis system. Ciência e Agrotecnologia, Lavras, v. 35, n. 6, p. 1039-1042, 2011.

FORSTHOFER, E. L.; SILVA, P. R. F.; STRIEDER, M. L.; MINETTO, T.; RAMBO, L.; ARGENTA, G.; SANGOI, L.; SUHRE, E.; SILVA, A. A. Desempenho agronômico e econômico do milho em diferentes níveis de manejo e épocas de semeadura. Pesquisa Agropecuária Brasileira, Brasília, v. 41, n. 3, p. 399-407, 2006.

MAGAlHÃES, P. C.; ALBUQUERQUE, P. E. P.; VIANA, J. H. M. Resposta fisiológica do sorgo ao estresse hídrico em casa de vegetação. Sete Lagoas: Embrapa Milho e Sorgo, 2012. 21 p. (EMBRAPA Milho e Sorgo. Boletim de Pesquisa e Desenvolvimento, 46).
MAY, A.; DURÃES, F. O. M.; PEREIRA FILHO, I. A. P.; SCHAFFERT, R. E.; PARRELLA, R. A. C. Sistema Embrapa de produção agroindustrial de Sorgo Sacarino para bioetanol Sistema BRS1G-Tecnologia qualidade Embrapa. Sete Lagoas: EMBRAPA Milho e Sorgo, 2012. 120 p.

MOREIRA, J. A.; STONE, L. F.; PEREIRA FILHO, I. A.; CRUZ, J. C. Eficiência de uso de água pela cultura do milho (Zea mays) em função da cobertura do solo pela palhada no sistema plantio direto. Cadernos de Agroecologia, Porto Alegre, v. 6, n. 2, p. 1-6, 2011.

OLIVEIRA, T. C.; SANTOS, P. R. J.; KOLLING, M. D.; BARELLI, M. A. A.; TARDIN, F. D.; LUZ, P. B. Desempenho agronômico de genótipos de sorgo sacarino na região de Cáceres-MT. In: CONGRESSO NACIONAL DE MILHO E SORGO, 30., 2014, Salvador. Anais... Sete Lagoas: Associação Brasileira de Milho e Sorgo, 2014. CD-ROM.

PEREIRA FILHO, I. A.; PARRELLA, R. A. C.; MOREIRA, J. A. A.; MAY, A.; SOUZA, V. F.; CRUZ, J. C. Avaliação de cultivares de sorgo sacarino (Sorghum bicolor (L.) MOENCH) em diferentes densidades de semeadura visando a características importantes na produção de etanol. Revista Brasileira de Milho e Sorgo, Sete Lagoas, v. 12, n. 2, p. 118-127, 2013.

PRASAD, S.; SINGH, A.; JAIN, N.; JOSHI, H. C. Ethanol production from sweet sorghum syrup for utilization as automotive fuel in India. Energy and Fuels, Washington, v. 21, n. 4, p. 2415-2420, 2007.

SCHLICHTING, A. F. Cultura do milho submetida a tensões de água no solo e doses de nitrogênio. 2012. Dissertação (Mestrado em Engenharia Agrícola) Universidade Federal de Mato Grosso, Rondonópolis.

SOUZA, E. D.; PARRELlA, R. A.; GRIGIO, M. L. Avaliação de cultivares de sorgo sacarino no cerrado de Roraima. In: CONGRESSO NACIONAL DE MILHO E SORGO, 30., 2014, Salvador. Anais... Sete Lagoas: ABMS, 2014. CD-ROM.

SOUZA, V. F.; PARRELLA, R. A.; PORTUGAL, A. F.; TARDIN, F. D.; DURÃES, N. N. L.; SCHAFFERT, R. E. Desempenho de cultivares de sorgo sacarino em duas épocas de plantio no Norte de Minas Gerais visando a produção de etanol. Búzios: SBMP, 2011. Disponível em: <http://ainfo.cnptia.embrapa.br/digital/bitstream/ item/40600/1/Desempenho-cultivares.pdf $>$. Acesso em: 24 jan. 2015. 
TARDIN, F. D.; CASASANTA, E. C.; PARRELLA, R. A. C.; SILVA, A. F.; BALDONI, A. B.; SOUZA, M. C.; BOTIN, A. A.; ZANATTO, I. B.; RAMOS JUNIOR, E. U.; SCHAFFERT, R. E. Desempenho agronômico de genótipos de sorgo sacarino cultivados em Sinop MT na Safra 2011/12. In: CONGRESSO NACIONAL DE MILHO E SORGO, 29., 2012, Águas de Lindóia. Anais... Águas de Lindóia: ABMS, 2012. p. 2389-2395.

TEIXEIRA, C. G.; JARDINE, J. G.; ZARONE, M. H. Influência da época de corte sobre o teor de açúcares de colmos de sorgo sacarino. Pesquisa Agropecuária Brasileira, Brasília, v. 34, n. 9, p. 1601-1606, 1999.
VAN GENUCHTEN, M. Th. A closed-form equation for predicting the hydraulic conductivity of unsaturated soils. Soil Science Society of America Journal, Madison, v. 44, n. 5, p. 892-898, 1980.

XIN, Z.; AIKEN, R.; BURKE, J. Genetic diversity of transpiration efficiency in sorghum. Field Crops Research, Amsterdam, v. 111, n. 1-2, p. 74-80, 2009. 